\title{
RELEVANKAH PANCASILA DAN GLOBALISASI? MENGUNGKAP HUBUNGAN PANCASILA DAN IDENTITAS GLOBAL
}

\author{
Maharani Ardi Putri \\ Fakultas Psikologi Universitas Pancasila \\ Jl. Raya Lenteng Agung, Srengseng Sawah, Jakarta Selatan \\ psyputri@gmail.com \\ Eko A Meinarno \\ Fakultas Psikologi Universitas Indonesia Kota Depok \\ snipsnape@yahoo.com
}

\begin{abstract}
This article discussed about globalization that eliminated physical borders between countries in the world so that it considered a variable of social change in various fields. One of the important issues related to globalization was whether globalization related to things that were typical of a group, namely the value of the dominant group and has advantages in various aspects of life. Indonesian society has a distinctive value, namely Pancasila. The study method used Pearson correlation analysis to test two significance of two variables, knowing the strong-weak relationship, and knowing the amount of retribution and to explain the degree of relationship between independent variables with dependent variables. This article also discussed about the measurement the relationship between values formulated in Pancasila and correlated with the global identity. The results obtained that the higher score of Pancasila equal with the person global identity score. This happens to all values of Pancasila. These results could be a marker that the value of Pancasila relevant for Indonesian people in the face of globalization.
\end{abstract}

Keywords: globalization, group values, Pancasila

\begin{abstract}
Abstrak: Artikel ini membahas tentang globalisasi yang meniadakan perbatasan fisik antara negaranegara di dunia sehingga dianggap sebagai variabel perubahan sosial masyarakat diberbagai bidang. Salah satu isu yang penting terkait globalisasi adalah apakah globalisasi berhubungan dengan halhal yang khas dari sebuah kelompok yakni nilai kelompok yang dominan dan mempunyai keunggulan dalam beragam aspek kehidupan. Masyarakat Indonesia mempunyai nilai khas yakni Pancasila. Metode kajian menggunakan analisis korelasi pearson untuk menguji dua signifikansi dua variabel, mengetahui kuat lemah hubungan, dan mengetahui besar retribusi serta untuk menjelaskan derajat hubungan antara variabel bebas (independent) dengan variabel terikat (dependent). Kajian ini bertujuan untuk mengukur hubungan antara nilai yang terumuskan dalam Pancasila dan dikorelasikan dengan identitas global. Hasil yang didapat adalah semakin tinggi skor nilai Pancasila semakin tinggi pula skor identitas global individu. Hal ini terjadi pada semua nilai Pancasila. Hasil ini dapat menjadi penanda bahwa nilai Pancasila relevan bagi masyarakat Indonesia dalam menghadapi globalisasi.
\end{abstract}

Kata kunci: globalisasi, nilai kelompok, Pancasila

Kehidupan masyarakat Indonesia telah bergeser dari lingkup lokal ke lingkup global. Perubahan pada era globalisasi, memberikan tantangan tersendiri bagi masyarakat Indonesia untuk terus membuka diri dan mengikuti arus perubahan, baik dalam keadaan siap ataupun tidak. Pemerintah Indonesia melakukan serangkaian pengukuran mengenai kemampuan masyarakat Indonesia, yang menghasilkan Kerangka Kualifikasi Nasional Indonesia (KKNI) pada tahun 2012. Menurut Kemenristek Dikti, KKNI merupakan kerangka penjenjangan kualifikasi sumber daya manusia Indonesia yang menyandingkan, menyetarakan, dan mengintegrasikan sektor pendidikan dengan 
sektor pelatihan dan pengalaman kerja dalam suatu skema pengakuan kemampuan kerja yang disesuaikan dengan struktur di berbagai sektor pekerjaan.

Berdasarkan KKNI kita dapat mengetahui hardskill yang dimiliki oleh manusia Indonesia, namun untuk sukses dalam persaingan global kita juga membutuhkan softskill yang sifatnya lebih psikologis. Kesiapan psikologis ini yang tampaknya belum banyak mendapat perhatian, tetapi sebenarnya memegang peranan penting. Kesiapan psikologis ini akan terkait erat dengan nilai yang diajarkan kepada setiap generasi mengenai halhal yang dianggap baik, dan nantinya nilai tersebut akan membentuk karakteristik kepribadian generasi berikutnya.

Nilai yang dianggap baik, dan diteruskan ada tiap generasi dan menjadi nilai dasar dalam membentuk kepribadian bangsa Indonesia tentunya merujuk pada nilai-nilai Pancasila. Perlu adanya pemetaan psikologis dari kesiapan masyarakat Indonesia. Jika kita mengakui dan menerima situasi serta kondisi globalisasi yang masuk ke dalam masyarakat. Selama ini hanya ada kalimat-kalimat bahwa terjadi perembesan globalisasi ke dalam masyarakat, tapi tidak diketahui seberapa besar perubahannya selain dari dampak perubahan perilaku yang seakan terjadi akibat globalisasi. Globalisasi menimbulkan arus perubahan yang cepat, sehingga perubahan ini dapat meningkatkan ketidakstabilan sosial dan mengurangi kekuatan negara.

Pada konferensi "Intercultural Leadership and Learning", dijelaskan oleh Panggabean, Muniarti, dan Tjitra (2015) bahwa berdasarkan hasil kajian mereka, manusia Indonesia memiliki tujuh kompetensi yang dapat digunakan untuk bersaing secara global. Tujuh kompetensi tersebut adalah: religiusitas, guyub, keberagaman, kepemimpinan fasilitatif, komunikasi tersirat, nrima, dan generalist serta technical (functional) excellence. Namun hal yang masih menjadi pertanyaan adalah apakah dengan tujuh kompetensi ini manusia Indonesia sudah dapat sukses bersaing secara global. Sedangkan kita semua tahu bahwa banyak kompetensi yang dianggap baik itu berasal dari nilai-nilai budaya "barat".

Merujuk pada posisi geografisnya. Indonesia adalah negara dalam posisi persimpangan. Bagi Indonesia isu pertukaran global bukan isu baru. Indonesia menjadi jalur bagi banyak pihak untuk berkomunikasi, khususnya perdagangan. Dari kawasan Amerika jika hendak ke India atau Timur Tengah akan melewati Indonesia dan arah sebaliknya. Saat ini Australia untuk menuju Asia Timur atau sebaliknya juga melewati Indonesia. Keadaan ini yang membuat masyarakat Indonesia selalu ramai dan terbuka dengan banyak pihak. Sejak lama sesungguhnya nilai masyarakat Indonesia bersinggungan dengan nilai dari masyarakat negara lain, sebagian dari nilai tersebut mungkin bercampur dengan nilai negara lain, namun ada pula nilai yang dipertahankan walaupun terus berbenturan.

Berdasarkan penjabaran di atas dapat dipahami bahwa bangsa Indonesia secara disadari maupun tidak sudah meletakkan dirinya dalam interaksi global. Manusia Indonesia sudah dapat melihat keterkaitan dirinya dengan seluruh bangsa, sehingga identitasnya tidak lagi sebatas sebagai masyarakat Indonesia tetapi juga sebagai masyarakat dunia. Itulah sebabnya kita bisa ikut merasakan kesenangan maupun kesedihan dari bangsa lain. Hal inilah yang dinamakan sebagai identitas global, di mana kita merasa menjadi bagian dari globalisasi.

Berdasar kondisi di atas maka kajian ini dibuat, sebagai kajian awal untuk mengetahui hubungan antara globalisasi dalam konteks identitas dan nilai. Kesiapan untuk perubahan bukan semata karena mengikuti lingkungan yang berubah, tapi juga kesiapan psikologis dari individu. Meskipun nilai tampak tetap bukan berarti tidak bergerak. Nilai juga akan mengikuti keadaan, karena salah satu faktornya adalah manusianya berubah seriring waktu. Kesiapan psikologis akan penulis lihat dari bagaimana individu menghayati nilai yang dimilikinya sesuai atau tidak dengan arus globalisasi. Nilai dalam penulisan ini adalah nilai nasional yang disepakati bersama yakni Pancasila. Sedangkan identitas global akan penulis lihat dari penghayatan Individu sebagai masyarakat dunia.

Berangkat dari ide globalisasi dan nilai nasional, yaitu Pancasila, maka diajukan argumentasi bahwa terdapat hubungan yang signifikan antara identitas global dan Pancasila pada semua nilai-nilainya. Dikarenakan nilai-nilai Pancasila dianggap mampu beradaptasi dengan perubahan jaman, maka kelanjutan dari argumentasi ini adalah ketika semakin tinggi penghayatan akan nilai-nilai Pancasila maka akan semakin tinggi pula identitas global seseorang.

Kata Pancasila pertama kali dikenalkan oleh Soekarno, dalam pidatonya untuk persiapan kemerdekaan Indonesia. Sebuah konsep yang 
tampaknya memang baru pertama kali muncul setidaknya untuk menyiapkan lahirnya sebuah negara Indonesia yang bukan kelanjutan Sriwijaya ataupun Majapahit. Pancasila berarti lima dan sila adalah asas atau dasar. Pada pidatonya ia tegaskan bahwa dengan Pancasila-lah Indonesia merdeka berdiri (Soekarno, 1945 dalam Sekretariat Negara Republik Indonesia, 1992).

Kelima sila ini secara prinsip tidak bisa dipisahkan satu sama lain. Hal ini dapat dirasakan ketika penulisan Pancasila itu sendiri yang bukan Panca Sila (terpisah). Kesatuan inilah yang kiranya menjelaskan bahwa karakter dari kontrak sosial ini adalah kesatuan. Terlebih saat hendak merdeka Indonesia secara de facto masih wilayah jajahan, sehingga dibutuhkan usaha untuk merekatkan kesatuan-kesatuan yang masih terpisah. Pancasila adalah modal "pengikat kesatuan" Indonesia (Meinarno, 2011)

Agak sedikit berbeda ketika Pancasila dibawa ke dalam perspektif psikologi. Pancasila diposisikan sebagai nilai sehingga Pancasila merupakan kumpulan lima nilai unidimensional yang dijadikan acuan tingkah laku bangsa Indonesia (Meinarno dan
Mashoedi, 2016). Kelima nilai yang terkandung dalam Pancasila adalah religio-toleransi (sila 1), kemanusiaan (sila 2), patriotisme-persatuan (sila 3), demokrasi (sila 4), dan keadilan sosial (sila 5). Nilai (values) adalah seperangkat keyakinan dan sikap mengenai bagaimana sesuatu itu seharusnya. Nilainilai melibatkan hal-hal yang dianggap penting oleh kita. Penempatan pentingnya nilai tak lepas dari pola hidup dasar manusia yang berkelompok. Nilai juga berfungsi untuk menenangkan diri dalam menghadapi kecemasan karena situasi dunia sekeliling tak menentu (Reykowski, 1997).

Pada penulisan ini, konsep Pancasila bukan ideologi atau dasar negara, tapi menjadi seperangkat nilai. Berdasar hal itu maka penulis menggunakkan operasionalisasi dari kajian-kajian sebelumnya tentang Pancasila. Pada tabel 1 diperlihatkan operasionalisasi Pancasila sebagai penghayatan nilai.

Nilai itu didesain atau setidaknya dipertahankan oleh kelompok yang menganggap nilai itu penting. Hal ini dapat dilihat dari beberapa kajian yang mengaitkan nilai dan keluarga atau kelompok etnis dan faktor pendidikan (Bar-Tal dan Staub, 1997; Ben-Amos, 1997).

Tabel 1. Nilai Pancasila dan operasionalisasinya (dalam Meinarno, 2013, 2016; Meinarno dan Mashoedi, 2016, Putri dan Meinarno, 2016)

\begin{tabular}{|c|c|c|}
\hline Nilai & Definisi & Rincian \\
\hline $\begin{array}{l}\text { Nilai pertama, } \\
\text { Ketuhanan Yang Maha } \\
\text { Esa (Religio-toleransi) }\end{array}$ & $\begin{array}{l}\text { Percaya pada Tuhan dan menjalankan } \\
\text { perintahnya sesuai keyakinan dan idak } \\
\text { memaksakan tkepercayaan pada orang lain }\end{array}$ & $\begin{array}{l}\text { faithfulness, toleransi pada } \\
\text { kelompok yang berbeda keyakinan, } \\
\text { spirituality and religiousness }\end{array}$ \\
\hline $\begin{array}{l}\text { Nilai kedua, } \\
\text { Kemanusiaan yang adil } \\
\text { dan beradab } \\
\text { (kemanusiaan) }\end{array}$ & $\begin{array}{l}\text { Mengakui persamaan hak dan kewajiban, } \\
\text { sayang pada sesama, menjalin hubungan } \\
\text { dengan bangsa lain berdasar sikap saling } \\
\text { menghormati }\end{array}$ & respek, fair, courage \\
\hline $\begin{array}{l}\text { Nilai ketiga, } \\
\text { Persatuan Indonesia } \\
\text { (patriotisme-persatuan) }\end{array}$ & $\begin{array}{l}\text { mengutamakan kepentingan bangsa daripada } \\
\text { diri/kelompok, cinta tanah air dan bangsa } \\
\text { dan mengembangkan rasa persatuan bagi } \\
\text { bangsa. }\end{array}$ & $\begin{array}{l}\text { loyalitas, kewarganegaraan } \\
\text { (memiliki pendirian yang kuat } \\
\text { terhadap kewajibannya, setia } \\
\text { kawan) }\end{array}$ \\
\hline $\begin{array}{l}\text { Nilai keempat, } \\
\text { Kerakyatan yang } \\
\text { dipimpin oleh hikmat } \\
\text { kebijaksanaan dalam } \\
\text { permusyawaratan } \\
\text { perwakilan (demokrasi) }\end{array}$ & $\begin{array}{l}\text { pengambilan keputusan berdasar musyawarah } \\
\text { untuk kepentingan bersama dengan tidak } \\
\text { memaksakan kehendak kepada orang lain, } \\
\text { dapat dipertanggungjawabkan dan } \\
\text { melaksanakan keputusan yang diambil. }\end{array}$ & tanggung jawab, harmoni \\
\hline $\begin{array}{l}\text { Nilai kelima, } \\
\text { Keadilan sosial bagi } \\
\text { seluruh rakyat Indonesia } \\
\text { (keadilan sosial) }\end{array}$ & $\begin{array}{l}\text { menjaga keseimbangan hak-kewajiban sosial } \\
\text { dengan mawas diri (dalam bentuk kualitas } \\
\text { luhur manusia) dan pengembangan diri yang } \\
\text { bertujuan untuk memajukan kehidupan sosial. }\end{array}$ & $\begin{array}{l}\text { persahabatan, keadilan dan } \\
\text { kerendahatian, menolong }\end{array}$ \\
\hline
\end{tabular}


Globalisasi adalah ketergantungan yang semakin meningkat antara bangsa-bangsa di sebuah sistem dunia yang terhubung secara ekonomi dan melalui media massa serta sistem transportasi modern (Meinarno, Widianto, Halida, 2015). Beberapa ciri sebuah negara atau bangsa telah ikut bagian dari globalisasi adalah masuk dalam organisasi dunia (NATO, WTO, dan lain-lain) dan mengandalkan perdagangan serta telekomunikasi modern (Meinarno, Widianto, Halida, 2015; Tsai, 2006). Hal yang agaknya terlupakan adalah bahwa globalisasi tidak hanya mempengaruhi negara, tapi individu juga dapat terpengaruh.

Penulisan tentang globalisasi dalam psikologi belum terlalu banyak. Salah satu yang memperhatikan masalah ini adalah Arnett (2002). Menurutnya salah satu aspek psikologis yang terpengaruh adalah identitas. Menurutnya pada kebanyakan masyarakat tumbuh gejala identitas bikultural. Hal ini ditandai dengan tumbuhnya identitas lokal yang terkait dengan kebudayaan global, misalnya kita menggunakan surat elektronik untuk berhubungan dengan orang lain, pada saat yang sama kita tetap menjalankan proses upacara siraman dalam pernikahan. Dengan demikianArnett (2002) menduga bahwa isu terpenting psikologi dalam masalah globalisasi adalah identitas.

Identitas global dalam penulisan ini adalah perasaan ikatan terhadap kebudayaan dunia yang di dalamnya termasuk kesadaran pada kejadian, praktek, gaya hidup dan informasi dari kebudayaan global (Arnett, 2002). Penulisan tentang identitas global dilakukan terhadap mahasiswa dengan berlatar etnis berbeda di Iran. Mereka berasal dari Azeri Turk (Azerbaijan), Fars, dan Kurdi di Universitas Tabriz. Hasil dari analisis menunjukkan bahwa ketika identitas global meningkat maka identitas lokalnya semakin rendah (Mahammadbakhsh, Fathiazar, Hobbi, Ghodratpour, 2011). Namun temuan ini juga tidak dapat digeneralisasi. Temuan lain oleh Tsai (2006) yang meneliti tentang globalisasi dan well being (wal afiat) menemukan bahwa dampak globalisasi di negara berkembang tidak terlalu kuat atau bermakna daripada di negara industri. Oleh karena analisisnya tidak dapat menguatkan dugaan bahwa globalisasi akan mengguncang stabilitas negara.

\section{METODE}

Metode pengambilan sampel yang digunakan adalah nonprobability sampling, yaitu tidak semua responden memiliki kesempatan yang sama untuk menjadi responden kajian. Teknik pemilihan sampel yang digunakan adalah acccidental sampling di mana responden yang dipilih adalah responden yang tersedia dan mudah dijangkau (Guilford \& Fruchter, 1978). Menurut Kerlinger dan Lee (2000) keuntungan dari acccidental sampling adalah memungkinkan penulis untuk memperoleh sampel dalam waktu yang cepat dan jumlah yang banyak.

Kriteria Responden kajian ini adalah mencapai pendidikan minimal SMP, sehingga sudah pernah mendapatkan pelajaran mengenai Pancasila dan mampu melakukan analisis sederhana mengenai penghayatan sila-sila Pancasila. Hal ini penting karena pendidikan dan kemampuan berpikir akan membantu seseorang dalam membuat pilihan dan memberikan tanggapan terhadap stimulus sosial.

Penulis meminta para mahasiswa yang pada tingkat dua untuk menjadi partisipan kajian ini. Langkah selanjutnya mereka membawa kuesioner yang sama untuk diminta diisikan kepada orangtua dari para mahasiswa tersebut, sehingga bias didapatkan varian usia yang cukup mewakili. Analisis data yang digunakan untuk melihat hubungan adalah dengan menggunakan korelasi product moment dari Karl Pearson. Kegunaan dari korelasi ini adalah untuk menguji dua signifikansi dua variabel, mengetahui kuat lemah hubungan, dan mengetahui besar retribusi. Dalam kajian ini analisis korelasi pearson digunakan untuk menjelaskan derajat hubungan antara variabel bebas (independent) dengan variabel terikat (dependent).

Variabel pertama dalam kajian ini adalah penghayatan nilai-nilai Pancasila atau keberPancasila-an. Variabel ini akan diukur dengan menggunakan kuesioner yang dikembangkan oleh Meinarno dan Suwartono (lihat Meinarno \& Suwartono, 2011; Suwartono \& Meinarno, 2011; Suwartono \& Meinarno, 2012; Meinarno \& Juneman, 2012) dengan menafsirkan penghayatan dari masing-masing sila. Jumlah total item pada alat ukur ini berjumlah 25 item. Untuk mengerjakannya, para partisipan memberikan tanda ketidaksesuaian hingga kesesuaian pada angka, sangat tidak sesuai/STS $=1$, tidak sesuai/ $\mathrm{TS}=2$, agak tidak sesuai/ATS $=3$, agak sesuai/ $\mathrm{AS}=4$, sesusai $/ \mathrm{S}=5$, sangat sesuai $/ \mathrm{SS}=6$. Masing-masing sila menjadi dimensi yang berbeda atau kelima sila dari Pancasila bersifat unidimen- 
sional, yang artinya masing-masing dapat berdiri sendiri dan tidak dapat digabungkan menjadi satu skor Pancasila. Item-item ini telah melalui proses uji reliabilitas dan validitas.

Alat ukur: nilai dan skala identitas global hasil adaptasi dari Tu, Khare, Zhang, (2012). Terdapat delapan pernyataan yang harus direspon. Adapun pengisiannya para partisipan memberikan tanda ketidaksesuaian hingga kesesuaian pada angka, sangat tidak sesuai/STS $=1$, tidak sesuai/TS $=2$, agak tidak sesuai/ATS $=3$, agak sesuai/AS $=4$, sesusai $/ \mathrm{S}=5$, sangat sesuai/ $\mathrm{SS}=6$.

\section{HASIL DAN PEMBAHASAN}

Pada bagian ini akan dibahas hasil-hasil kajian. Hal yang akan diperlihatkan adalah gambaran partisipan. Partisipan sebanyak 59 orang atau $71 \%$ adalah perempuan, 20 orang $(24 \%)$ lelaki dan ada empat orang (1\%) yang tidak memberikan keterangan jenis kelamin. Untuk etnis, 45 orang atau $54 \%$ beretnis Jawa. Lainnya beragam dengan jumlah yang tidak banyak, misalnya yang beretnis Batak hanya dua orang.

Berikut hasil penghitungan hubungan antara Pancasila dengan identitas global.

1. Terdapat hubungan yang signifikan antara sila 1 dengan identitas Global. Hal ini ditunjukkan dengan hasil nilai signifikansinya sebesar 0,011 $\mathrm{p}>0,05 .\left(, 279^{*}, 0,05 ; 2\right.$-tailed $)$

2. Terdapat hubungan yang signifikan antara sila 2 dengan identitas global. Hal ini ditunjukkan dengan hasil nilai signifikansinya sebesar 0,015 $\mathrm{p}<0,05$. (,267*, 0,05; 2-tailed).

3. Terdapat hubungan yang signifikan antara sila 3 dengan identitas global. Hal ini ditunjukkan dengan hasil nilai signifikansinya sebesar 0,000 $\mathrm{p}<0,01$. (,416**, 0,01; 2-tailed).

4. Terdapat hubungan yang signifikan antara sila 4 dengan identitas global. Hal ini ditunjukkan dengan hasil nilai signifikansinya sebesar 0,020 $\mathrm{p}<0,05$. (,254*, 0,05; 2-tailed).

5. Terdapat hubungan yang signifikan antara sila 5 dengan identitas global. Hal ini ditunjukkan dengan hasil nilai signifikansinya sebesar 0,020 $\mathrm{p}<0,05$. (,256*, 0,05; 2-tailed),

Masing-masing hubungan di atas memiliki hubungan yang sifatnya positif, oleh karenanya, berdasar hal tersebut maka semakin tinggi skor penghayatan pada masing-masing sila maka semakin tinggi pula identitas global individu. Berdasar urutan maka nilai Pancasila dari yang paling kuat hubungannya adalah sila ketiga, sila pertama, sila kedua, sila kelima, dan sila keempat.

Hasil dari kajian ini cukup menarik. Hasil ini membangun pernyataan ilmiah bahwa terdapat hubungan yang signifikan antara penghayatan nilainilai Pancasila dengan identitas Global. Hasil ini tidak sejalan dengan temuan Mahammad bakhsh, Fathiazar, Hobbi, Ghodratpour (2011) yang mengindikasikan hubungan yang berlawanan antara identitas global dan identitas lokal. Temuan dari riset ini cenderung dekat dengan kajian Tsai (2006). Apa yang kira-kira menyebabkan hasil ini muncul?

Sebagaimana riset ini yang mengajukan variabel psikologis khas Indonesia yakni Pancasila. Pancasila sebagai nilai tidaklah muncul begitu saja. Sebagaimana cara pikir Soekarno saat mengajukan Pancasila sebagai pandangan hidup di rapat BPUPK tahun 1945, bahwa Pancasila tidak steril dari faktor kebudayaan asing. Pancasila digali dari lapisan-lapisan sejarah bangsa Indonesia yang tiap lapisnya terdapat unsur kebudayaan dominan asing, tentu dapat menjadi penegasan bahwa pengaruh faktor budaya sangat penting.

Posisi Indonesia sebagai daerah persimpangan menjadikannya tak lepas dari pihak luar. Jika memang Indonesia tidak mau ikut arus globalisasi, tapi posisinya mengharuskannya menjadi sistem penghubungan perdagangan bangsa-bangsa, maka dengan demikian warga Indonesia seakan terikat secara alami dengan globalisasi.

Pancasila juga berkontribusi terhadap pembentukan identitas nasional Indonesia (Suwartono \& Meinarno, 2011). Sebagaimana temuan Tsai (2006), Indonesia juga belum menjadi negara industri maju sehingga dampak globalisasi tidak cukup kuat. Untuk lebih memperjelas adalah penting melihat salah satu nilai Pancasila yang paling kuat korelasinya yakni nilai ketiga. Nilai ketiga adalah mengutamakan kepentingan bangsa daripada diri/kelompok, cinta tanah air dan bangsa dan mengembangkan rasa persatuan bagi bangsa (tabel 1). Merujuk definisi variabel nilai ketiga maka apa yang diajukan Arnett (2002) adalah benar. Identitas sebagai warga global tinggi, diikuti secara positif kecintaan pada bangsa dan negara. Nilai ketiga bukan sebuah nilai nasionalisme sempit sebagaimana yang ditunjukkan Nazi Jerman dibawah Hitler. Nilai yang dikembangkan cenderung rasa cinta pada negara (patriotisme). Kajian yang menegaskan hubungan nilai ketiga 
dan patriotisme juga telah dilakukan dan menghasilkan pola yang sama (Putri \& Meinarno, 2016).

Hubungan kuat nilai ketiga dan identitas global dapat diterangkan dengan gejala yang diajukan Arnett (2002). Bahwa tumbuhnya identitas sangat lekat dengan interaksi sehari-hari dengan keluarga, teman dan anggota komunitasnya. Tidaklah mengherankan jika kemudian para responden dalam tulisan ini terikat dengan nilai ketiga sebagai perwujudan cinta pada tanah air. Di sisi lain perkembangan teknologi tetap diikuti atau tetap ikut menjadi warga dunia tanpa khawatir berlawanan dengan nilai yang dianut.

Hasil dari kajian ini memperkuat pendapat Arnett (2002), dan Tsai (2006), sehingga dapat disimpulkan bahwa kehidupan bikultural sangat mungkin terjadi. Perpaduan geografis, cara pandang, dan keadaan negara juga patut dipertimbangkan sebagai aspek lain dari kuat tidaknya identitas global.

Kajian ini masih mempunyai pertanyaanpertanyaan yang dapat memperkuat atau melemahkan hasil yang ada. Tulisan ini belum menjelaskan pengaruh dari globalisasi terhadap nilai Pancasila. Gejala ini perlu diperhatikan mengingat korelasi nilai dan identitas global yang kuat. Selain itu karakteristik responden yang belum dibandingkan, dimana tiap generasi akan menghasilkan pola hubungan yang berbeda. Tentu hal ini menarik, terlebih dengan keadaan Indonesia yang sudah jelas masuk arus globalisasi dengan

\section{DAFTAR RUJUKAN}

Arnett, JJ. The psychology of globalization. American Psychological Association. Vol. 57, No. 10, 2002, 774-783.

Dewi, RI., Soemiarno, S., Poerbasari, AS., Meinarno, EA. 2013. Buku ajar III: Bangsa, Negara, dan Pancasila. Depok. Universitas Indonesia.

Flum, H., Cinamon, RG. Immigration and the interplay among citizenship, identity and career: The case of Ethiopian immigration to Israel. Journal of Vocational Behavior 78 (2011) 372-380.

Mahammadbakhsh, B., Fathiazar, E., Hobbi, A., Ghodratpour, M. Globalization and local and global identities among Iranian students. International Journal of Intercultural Relations 36 (2012) 14-21. penduduk yang pola generasinya terdiri dari generasi $\mathrm{X}, \mathrm{Y}$ dan bahkan milenial. Dengan demikian isu kajian ini masih akan berkembang, khususnya dari perspektif bidang psikologi.

\section{SIMPULAN}

1. Pernyataan ilmiah dari hasil kajian menunjukan bahwa terdapat hubungan yang signifikan antara penghayatan nilai-nilai Pancasila dengan identitas global. Hal ini berdasarkan perhitungan dari sampel responden yang menunjukan bahwa semakin tinggi skor penghayatan pada masing-masing nilai sila pada Pancasila maka semakin tinggi pula identitas global individu. Pemahaman ini diperkuat berdasarkan kajian bahwa Pancasila sebagai nilai tidaklah muncul begitu saja, melainkan Pancasila digali dan muncul dari lapisan-lapisan sejarah bangsa Indonesia yang tiap lapisnya terdapat unsur kebudayaan asing yang merupakan unsur dasar identitas global.

2. Dari beberapa nilai dalam Pancasila, salah satu nilai Pancasila yang paling kuat korelasinya dengan identitas global yakni nilai ketiga. Identitas sebagai warga global tinggi, diikuti secara positif kecintaan pada bangsa dan negara. Nilai ketiga adalah mengutamakan kepentingan bangsa daripada diri/kelompok, cinta tanah air dan bangsa dan mengembangkan rasa persatuan bagi bangsa serta mendukung persatuan dan perdamaian antar bangsa.

Meinarno, E.A. 2011. Representasi Sosial dari Pancasila: Konteks Remaja Indonesia. Disampaikan pada seminar nasional psikologi multikulturalisme di Kudus, 9 Mei 2011.

Meinarno, EA. 2016. Pancasila. Dalam Buku Matakuliah Pengembangan Kepribadian Terintegrasi A. dalam proses penerbitan. Univrsitas Indonesia. Depok.

Meinarno, EA. Pancasila dan merah putih di serambi Mekah. Jurnal Pancasila Vol. 1. No. 1. 2014. Hlm. 52-59.

Meinarno, EA., Juneman. Validasi konkuren skala keber-Pancasila-an pada remaja mahasiswa di Jakarta. Insan. Vol. 14. No. 1. April 2012. 
Meinarno, EA., Mashoedi, SF. Pembuktian kekuatan hubungan antara nilai-nilai pancasila dengan kewarganegaraan. Jurnal Ilmiah Pendidikan Pancasila dan Kewarganegaraan. Vol 1, No 1 (2016): Juni 2016. Hal. 12-22.

Meinarno, EA., Suwartono, C. The Measurement of Pancasila: An Effort to make Psychological Measurement from Pancasila Values. Jurnal Ilmiah Mind Set. Vol. 2 No. 2. Juni 2011. 104-110.

Panggabean, H., Muniarti, J., dan Tjitra, H. 2015. Kesiapan Manusia Indonesia Dalam Persaingan Global. http://www.atmajaya.or.id,

Patnaik, P. Nation-State in the Era of 'Globalisation'. Source: Economic and Political Weekly, Vol. 30, No. 33 (Aug. 19, 1995), pp. 2049-2053.

Putri, MA., Meinarno, EA. Studi Lintas Generasi: Penghayatan Pancasila dan Patriotisme Pada Era Globalisasi. Prosiding Seminar Nasional Psikologi Indigenous Indonesia 2016: Kebhinekaan dan Masa Depan Indonesia: Peran Ilmu Sosial dalam Masyarakat, Malang, 27-28 Agustus 2016.

Radhakrishnan, P. Religion under Globalisation. Economic and Political Weekly, Vol. 39, No. 13 (Mar. 27 - Apr. 2, 2004), pp. 1403-1411.

Roy, A. Civil Society and Nation State: In Context of Globalisation. Economic and Po- litical Weekly, Vol. 30, No. 31/32 (Aug. 512, 1995), pp. 2005-2010.

Salzman, MB. Globalization, religious fundamentalism and the need for meaning. International Journal of Intercultural Relations 32 (2008) 318-327.

Schmidt, A. Globalization, Neoliberal Ideology, and National Identity: The Historical Uncertainties of NAFTA. Caribbean Studies, Vol. 29, No. 1, For Better or Worse: The Caribbean and NAFTA. (Jan. - Jun., 1996), pp. 67-105.

Staeheli, LA. Globalization and the scales of citizenship. Geogrpahic Research Forum Vol. 19, 1999, 60-77.

Suwartono, C. Meinarno, EA. Value orientation scale: The validation of Pancasila Scale. Jurnal Pengukuran Psikologi dan Pendidikan Indonesia. Vol. 1. No. 3. Juli 2012. 175-183.

Suwartono, C., Meinarno, EA. Construct Validation of Pancasila Scale: An Empirical Report. Dipaparkan pada ICRAS, Yogyakarta, Juli 2011.

Tsai, M-C. Does Globalization Affect Human Well-Being?. Social Indicators Research (2007) 81: 103-126.

Tu, L., Khare, A., Zhang, Y. A short 8-item scale for measuring consumers' local-global identity. Intern. J. of Research in Marketing 29 (2012) 35-42. 